\title{
DA CEGUEIRA À ORFANDADE: A QUESTÃO DA CIDADANIA NAS POLÍTICAS DE ALFABETIZAÇÃO DE JOVENS E ADULTOS (1947 - 2002)
}

\author{
Marcia Soares de Alvarenga ${ }^{1}$ \\ UERJ
}

\section{RESUMO:}

No Brasil, as iniciativas que envolvem as políticas governamentais de alfabetização de jovens e adultos parecem confirmar, cada vez mais, a inexorável existência de sua conexão com os modelos políticos e econômicos que foram e continuam sendo desenvolvidos no país, condicionando a questão da cidadania aos marcos ideológicos determinados por estes modelos. As políticas governamentais de alfabetização, destinadas aos jovens e adultos excluídos do processo de escolarização, são instruídas como "missões civilizatórias" que, transformadas em "campanhas", "cruzadas" ou "movimentos", tentam promover a erradicação da diferença entre a barbárie e a civilização; entre a não-cidadania e a cidadania, conduzindo, pelo estandarte da alfabetização, a mensagem ideológica que atribui à ausência, à falta da leitura e da escrita a raiz fundante de tais diferenças. A perspectiva de análise, adotada neste trabalho, assume como tarefa definir como a categoria cidadania vem sendo construída nas políticas oficiais de alfabetização de jovens e adultos, marcando-a com concepções e referenciais próprios do pensamento das classes hegemônicas no Brasil, produzindo a "ideologia do analfabetismo".

Palavras-chave: Educação de Jovens e Adultos - Políticas de alfabetização - cidadania ideologia

\section{FROM BLINDNESS TO ORFANHOOD: QUESTIONING CITIZENSHIP IN LITERACY POLICIES AIMED AT YOUNG PEOPLE AND ADULTS (1947-2002)}

\begin{abstract}
:
In Brazil, initiatives involving governmental policies on young persons' and adult literacy seem to confirm more and more their inexorable connection to political and economic models that have previously been and continue to be elaborated in the country, conditioning citizenship to ideological marks determined by these models. Governmental literacy policies, destined for young people and adults who have been excluded from traditional schooling are instructed as if they were part of a 'civilizing mission' which, transformed into a 'campaign' or 'crusade' or 'movement', proposes eradicating the gap between Barbary and civilization; citizens and non-citizens, conducting through the literacy banner the ideological message that would have a lack of reading and writing capabilities as the founding root of such gaps. The analytical perspective adopted in this paper strives to define citizenship as a category constructed in official policies of promoting literacy among youngsters and adults, branding them with concepts and references proper to the hegemonic classes in Brazil, producing an 'ideology of literacy'. Keywords: Educating Young people and adults - Literacy policies - citizenship - ideology
\end{abstract}


A história de vida de um pobre é escrita em sua pele, com uma caneta bem fina.

Aravind Adiga (2008)

No Brasil, a ideia de cidadania parece teimar em ser traduzida, ao menos discursivamente, como a experiência do inacabado, de algo sempre a se construir, do enigma que não pôde ser decifrado no passado e que nos desafia no presente.

Entretanto, como nos lembra Martins, "a cidadania não é o milagre do discurso fácil; onde é real e tem sentido, não foi produzida pela cansativa repetição da palavra que a designa” (1994, p.12).

Com esta afirmação, Martins nos provoca a pensar que a questão da cidadania no Brasil não pode ser solucionada pelo discurso da alfabetização e, menos ainda, analisada e compreendida, apenas, pelo paradigma das teorias clássicas que tomam, como marco inaugural da evolução dos direitos de cidadania, os processos revolucionários que tiveram como cenário a França e a Inglaterra dos séculos XVII e XVIII.

Muito embora os direitos de cidadania tenham se tornado irrealizáveis para a maioria da população, considerando, sobretudo, que o direito à propriedade era critério que determinava quem deveria ser mais sujeito de direitos do que outros, a experiência da participação de camponeses pobres e assalariados da cidade, como protagonistas no processo revolucionário, marcará a questão da cidadania como uma construção histórica produzida por lutas e conflitos que perpassam não apenas as classes sociais mas, também, os interesses das chamadas "minorias" étnicas, culturais e de gênero que emergem dos novos contextos na contemporaneidade.

A emergência histórica da cidadania nas sociedades modernas e democráticas nos faz refletir a realidade da cidadania no Brasil, seus impasses e (in)viabilidades, ainda, na contemporaneidade.

A existência de milhões de desempregados, analfabetos, trabalhadores rurais semterra, trabalhadores urbanos sem-teto, pobreza no campo e na cidade, salários injustos que não reproduzem a força do trabalho, a perda da infância de meninos e meninas de rua e a perversa concentração de renda são problemas que nos empurram, cada vez mais, para um apartheid social e nos questionam se, em algum momento de nossa história, fomos cidadãos.

Assim, ao recuperarmos o discurso ideológico que permeia as políticas públicas de alfabetização de jovens e adultos, não podemos nos opor a ele, simplesmente, negando-o com um outro discurso, mas por um movimento interno de construção de um discurso crítico e práticas emancipatórias que sejam capazes de evidenciar as contradições denunciadoras das suas lacunas impreenchíveis.

A perspectiva ideológica também vincula-se às dimensões histórica e sociológica da questão da cidadania no Brasil. A trajetória brasileira de construção da cidadania, a partir dessas dimensões, vem sendo marcada e matizada pela cultura colonial, preservada e renovada pelo autoritarismo das elites, pela tradição oligárquica, pela indistinção entre o público e o privado e pelo clientelismo como cultura política de "dar e receber privilégios".

A análise de Martins (1994), à luz dessa trajetória, nos ajuda a pensar que a problemática da cidadania brasileira é própria de uma sociedade de origem colonial que permite identificá-la, como ele a designa, como uma "sociedade de história lenta".

Ao fazer uma leitura crítica de importantes acontecimentos e fatos verificados em nossa história social, econômica e política, Martins argumenta a necessidade de perscrutarmos e distinguirmos a presença viva e ativa de estruturas fundamentais do passado, na sociedade brasileira contemporânea. 
Assumindo esta perspectiva, este autor produz uma importante síntese sobre a formação social e econômica da sociedade brasileira ao afirmar terem as elites oligárquicas vestido a máscara do liberalismo e das políticas modernas sem, contudo, terem sido obrigadas a abrirem mão de seus interesses com o latifúndio imobilizador do progresso e do clientelismo como forma de exercício do poder político.

A perpetuação dessas antigas estruturas concebeu o atraso como um instrumento do poder e, como tal, parece teimar em nos impedir de construir um projeto de cidadania que rompa com essas fundações.

A prática do clientelismo, a corrupção, a questão da propriedade latifundiária e a tradição oligárquica, presente no Brasil contemporâneo fazem com que a construção dos sentidos da cidadania no Brasil continue a pagar pesados tributos políticos e sociais. Melhor dizendo, o sentido da não-cidadania no Brasil deve-se ao "poder do atraso" mantido e revigorado pelas elites autoritárias brasileiras que buscam renovar-se.

\section{Os direitos de cidadania no Brasil: política e analfabetismo na cidadania invertida}

A partir de uma abordagem histórica, encontro na pesquisa de Carvalho (1995) um importante referencial que nos convida a trilhar os labirintos do desenvolvimento da cidadania no Brasil. Em seus estudos este autor analisa que a perspectiva liberal dos direitos civis, políticos e sociais se efetivou de forma invertida em nosso país, ou seja, primeiro foram conquistados os direitos políticos, depois os direitos civis e, por último, continuam sendo reivindicados os direitos sociais.

Este assunção teórica deve-se à análise de que, diferentemente dos países onde se erigiu a cidadania moderna, a cidadania brasileira não se originou de nenhum conflito antagônico de classes fundamentais, nem obedeceu a uma evolução de direitos, tal como pressupõe a análise clássica desenvolvida por Marshall (1967).

O caráter nada revolucionário das classes dirigentes e dominantes impediu o desenvolvimento de alguns direitos em detrimento de outros. Este caráter é tributado à herança colonial portuguesa, cujo legado - formado pela escravidão, pelos latifúndios e por um Estado comprometido com os interesses privados por não ter sido radicalmente combatido e rejeitado, consolidou-se como forte barreira ao desenvolvimento da cidadania no Brasil.

Particularmente em relação à escravidão, o princípio liberal do direito à liberdade individual, isto é, dos direitos civis, tornou-se impossível de se compatibilizar com a prática generalizada da escravidão, pois não havia linhas geográficas ${ }^{2}$ que separassem a escravidão da liberdade, na sociedade liberal-escravocrata.

Do mesmo modo, há que se observar que o direito político, fundado na idéia de que todos podem exercer o poder do voto em uma sociedade democrática, foi decreto extinto para a imensa população brasileira constituída por analfabetos.

É interessante assinalar que a interdição do direito político ao voto ao analfabeto não fazia parte da tradição política brasileira, muito embora houvesse no pensamento político o interesse de afastá-lo como, de fato viria acontecer após a instituição da lei de 1881, elaborada por eminentes e entusiasmados defensores dos ideais do liberalismo, entre os quais Rui Barbosa era seu principal representante.

A passagem do regime imperial para o regime republicano irá agravar as desvantagens políticas entre o cidadão ativo e o cidadão passivo, no que diz respeito ao gozo do direito político. Diferentemente do Império que adotava duplo critério para o direito ao voto, ou seja, o critério censitário da renda e o critério capacitário ao voto, sem que deste fosse excluído o analfabeto, o regime liberal republicano irá abolir o primeiro 
critério, mas manterá o regime capacitário, inclusive ampliando-o com a negação deste direito aos analfabetos (FAORO, 1998; RODRIGUES, 1981).

A partir da lei Saraiva de 1881, a exclusão do analfabeto passou a ser um princípio das Constituições republicanas que continuaram a discriminar o voto popular de mendigos, religiosos, marinheiros, soldados e analfabetos, negando-lhes a cidadania política.

$\mathrm{O}$ argumento dos liberais favoráveis à exclusão constitucional dos analfabetos apoiava-se na idéia de que o impedimento da capacidade eleitoral desta população serviria para pressionar o governo a oferecer instrução básica e escolas a "esses analfabetos que se excluem do corpo eleitoral". 3

Esta decisão de uma minoria a comandar as maiorias analfabetas, mantidas sem voz nas urnas até que o seu direito ao voto fosse proclamado e instituído na Constituição "Cidadã" de 1988, irá se constituir como uma das mais poderosas teses do liberalismo sobre a incapacidade do povo, iletrado e inculto, de participar da vida política do Estado.

Paradoxalmente, ao invés de impulsionar a universalização do direito à educação, a exclusão dos analfabetos pelas constituições liberais, se tornará, cada vez mais, injustificavelmente discriminatória e contraditória,

(...) pois ao mesmo tempo se retirava a obrigação do governo de fornecer instrução primária, que constava do texto imperial. Exigia-se para a cidadania política uma qualidade que só o direito social da educação poderia fornecer (CARVALHO, 1995, p.45).

Esta concepção só começou a ser revista quando o processo de reestruturação econômica, pelo qual passou a formação social brasileira, veio substituir a velha estrutura econômica colonial agrária pelo novo modo de produção capitalista. Será durante esse processo que a alfabetização ganhará o status de importância para o desenvolvimento do estado capitalista, impulsionando o movimento de campanhas e programas de alfabetização de jovens e adultos.

As fórmulas pactuadas e conciliatórias feitas entre as elites apequenaram o Estado democrático e de direito, resultando num Estado para poucos brasileiros e não para todos os brasileiros. A lenta e complexa construção histórica dos sentidos da cidadania no Brasil possuem algumas particularidades que envolvem, sobretudo, a própria forma como as elites dirigentes e dominantes passaram a assumir a questão da democracia.

É como resultado das formas de pactuação adotadas que os sentidos da democracia brasileira fizeram com que os direitos civis, políticos e sociais fossem ampliados ou restringidos, em diferentes períodos históricos, produzindo uma situação de dissincronia entre eles.

Essa situação pode ser mais bem percebida nos marcos da Revolução de 30 e no regime militar autoritário, instituído no Brasil em 1964. Assim, enquanto os direitos sociais eram pouco mais ampliados (os direitos trabalhistas em 30 e a legislação dos trabalhadores rurais em 64), inversamente, os direitos civis e políticos eram tripudiados, sendo os movimentos sociais e de trabalhadores esmagados pelos aparelhos repressores do Estado.

$\mathrm{O}$ entendimento de que a democracia é o fundamento para se refletir sobre os sentidos da cidadania, merece ser explicitado mais detidamente. Há poucas dúvidas em relação ao fato de que pensar sobre os sentidos da democracia é pensar sobre os sentidos da cidadania, pois, ao que parece, é sob o pano de fundo da democracia que um conjunto de direitos podem ser assegurados.

O movimento existente entre estes sentidos são reveladores de uma reciprocidade que, muito embora tenha servido de arcabouço da burguesia consagrando sua perspectiva 
de cidadania e de democracia, mantiveram-se em pólos opostos ou desencontrados na recente história liberal-republicana brasileira.

O perfil intervencionista do Estado subordinou os sentidos da cidadania a uma perspectiva autoritário-corporativa, imprimindo à força o controle sobre os movimentos sociais e organizações de trabalhadores e, ainda, impondo um modelo corporativista de gestão das políticas sociais.

Com efeito, os sentidos da cidadania no Brasil foram produzidos através de duas concepções procedentes do estatuto oficial de cidadania homologada: a "cidadania regulada", pós Estado Novo; e "a cidadania em recesso", a partir de 1964 (SANTOS, 1987).

Para Santos, o sentido da cidadania regulada encontra suas raízes,

(...) não em um código de valores políticos, mas em um sistema de estratificação ocupacional e que, ademais, tal sistema (...) é definido por norma legal (...). São cidadãos todos aqueles membros da comunidade que se encontram localizados em qualquer uma das ocupações reconhecidas e definidas em lei. (...). A cidadania está embutida na profissão e os direitos restringem-se aos direitos do lugar que ocupam no processo produtivo (1987, p.68).

Em relação a essa "modalidade" de cidadania, seu sentido é atribuído ao recesso da cidadania política, pelo não reconhecimento do direito ou da capacidade da sociedade governar-se a si própria. A cidadania passa a ter sentido pela via dos atos normativos onde são definidas as obrigações e as expectativas do Estado em relação aos membros da sociedade.

A despeito destes sentidos de cidadania atribuídos pelo autoritarismo do Estado, deve-se observar que este possuiu um projeto de cidadania para os seus subordinados, pois molda o cidadão consoante aos pontos de vista das forças sociais que lhe deram sustentação.

Estas breves considerações corroboram na idéia de que, necessariamente, é preciso fazer combinar cidadania e democracia, considerando serem os seus sentidos tensionados pelas forças sociais e pelas formas de relações que as trespassam.

Certamente que não se pode desprezar, em absoluto, a complexa relação existente entre os contextos histórico-político-sociais e econômicos e os sentidos da cidadania, particularmente em relação ao contexto da década de 1980.

Milton Santos (1996) analisa que a grande crise econômica do capitalismo de livre mercado levou, sobretudo, os países do Terceiro Mundo a retrocederem em certas embora nem sempre extensivas - conquistas sociais e políticas dos seus povos.

O caso brasileiro toma maior magnitude no pensamento deste geógrafo. Para ele em nenhum outro país do mundo os processos de desruralização, migrações brutais desenraizadoras, urbanização, a expansão do consumo de massas, entre tantos outros fatores, se efetivaram de forma tão concomitante e avassaladora como no Brasil nos últimos trinta anos.

Santos atribui ao modelo político-econômico, particularmente àquele relacionado ao "milagre brasileiro", a responsabilidade pela eliminação do embrião de cidadania que no Brasil se gestava. $\mathrm{O}$ "milagre" operou pelo alargamento de uma nova classe média em detrimento das massas pobres e populares, aumentando as disparidades sociais e econômicas entre estes segmentos. Dessa forma, o desenvolvimento econômico acelerado, durante este período, dispensou a redistribuição de renda e diminuiu a capacidade do Estado de fazê-la. 
O que passamos a assistir foi o crescimento econômico baseado em certos setores produtivos e em certos lugares, agravando a concentração de riqueza e a ampliação das injustiças entre as pessoas e entre os lugares.

Desse modo, todo o equipamento do país destinado ao escoamento rápido e mais fácil da produção serviu ao modelo econômico que o gerou para a criação do modelo territorial a ele correspondente: grandes migrações (muito mais de consumo do que de trabalho, esvaziamento demográfico de inúmeras regiões, concentração da população em crescimento, principalmente em áreas urbanas e formação de grandes metrópoles em todas as regiões).

Os impactos produzidos pelos modelos econômico e territorial criaram um "arremedo" de sociedade de massas, sem que, necessariamente, tenha correspondido a um concomitante e real consumo de massas.

A notável análise feita por Santos sobre o contexto contemporâneo históricopolítico e social da sociedade brasileira traz como novidade a profunda preocupação em relação aos sentidos da cidadania no Brasil: um território que, em virtude dos modelos econômicos excludentes, tem sido habitado por menos cidadãos e mais não-cidadãos. Para ele, o modelo econômico adotado pelo país nas últimas décadas metamorfoseou a cidadania, então renascida, pela ideologia do consumo e da prosperidade. Através desta ideologia criou-se a impressão de que as populações, sobretudo, as classes médias, gozavam de inesgotável realização pessoal.

Desse modo, nos fala Santos, em "lugar do cidadão formou-se um consumidor, que aceita ser chamado de usuário" (idem, p.13). A ideologia do consumo e da prosperidade atinge a sociedade de alto a baixo, e, mesmo que o mapa da pobreza se amplie, o empenho da mídia, aliada à empreitada do esvaziamento da esfera pública e à privatização do Estado pelas políticas neoliberais, construiu a miragem da prosperidade.

A ideologia do consumo associou-se em fins da década de 1980 e na década de 1990 à ideologia da competitividade, ambas engordadas pela globalização e as práticas político-econômicas neoliberais, naturalizando a existência de cidadanias desiguais: a cidadania de primeira-classe e as de segunda e terceira classe.

A tirania da informação e da expansão do paradigma da avareza ${ }^{4}$ representada pelos grandes organismos que comandam a produção e as finanças do mundo tornariam a competitividade uma regra de existência coletiva e individual.

Tanto a ideologia do consumo quanto a ideologia da competitividade, nos assegura Santos (2000), levam a esquecer a oposição que há entre a figura do consumidor e a figura do cidadão.

Com efeito, lembra a tempo este autor, no Brasil esta oposição é muito pouco sentida

(...) porque em nosso país jamais houve a figura do cidadão. As classes chamadas superiores, incluindo as classes médias, jamais quiseram ser cidadãs, os pobres jamais puderam ser cidadãos. As classes médias foram condicionadas a apenas querer privilégios e não direitos (2000:, p.49-50).

Estas observações de Santos vão de encontro com as perspectivas de outros autores preocupados em decifrar os sentidos da cidadania invertida legitimados no Brasil pelas suas elites. Como destaquei, anteriormente, pode-se depreender que a experiência do movimento liberal europeu pelos direitos de cidadania não se repetiu da mesma maneira no Brasil. Ao contrário, estes foram explícita e formalmente colocados dentro do círculo vicioso dos privilégios ao qual poucos poderiam ter acesso. 
O fundamento do privilégio foi o que moveu e move a sociedade brasileira, orientou a organização e o funcionamento político-partidário no Brasil. No entanto, observa Santos ${ }^{5}$, a classe média está agora descobrindo a cidadania; está descobrindo que nem sempre pode ter privilégios, pois nem sempre tem poder político, nem sempre os partidos políticos a representam na defesa e manutenção dos seus privilégios.

A redescoberta da cidadania, no sentido de direitos e não no sentido de privilégios, tem um formidável alcance político e filosófico para o Brasil, pois nutre a consciência dos setores de que é preciso lutar por direitos de cidadania e não pela obtenção e manutenção de privilégios que servem a poucos e legitimam a desigualdade social.

Com efeito, a relação entre alfabetização e cidadania precisa ser complexificada a partir destes contextos, já que, ao que me parece, sob a regência ideológica dos modelos liberal e neoliberal, as políticas de alfabetização têm sustentado as motivações de que o acesso à cidadania só é possível via alfabetização e escolarização cada vez mais exigidas pelas demandas tecnológicas da produção econômica e das novas regras do mercado.

É a partir destes contextos que busco analisar processos de imputação do silêncio em relação aos sentidos possíveis da cidadania, alienado na díade alfabetização e cidadania, bem como as resistências dos alfabetizandos face à hegemonia de sentido que o Programa Alfabetização Solidária (PAS) empreende em assegurar.

\title{
2 - Os sentidos da cidadania: entre vozes e silenciamentos nas políticas de alfabetização de jovens e adultos
}

\author{
-A pessoa que não sabe ler é que nem diz o ditado: a pessoa \\ que não sabe ler é cega. Quem não sabe ler, morre de \\ graça. Se diante de uma placa que avisa 'Perigo, não \\ atravesse', e agente atravessar, estamos praticamente \\ morto... \\ - E ser cego pra você é isso? \\ Nesse sentido é sim. E não no sentido da vista e sim, no \\ sentido da leitura que eu falo pra você (Jadson, trabalhador \\ rural de aluguel, 25 anos).
}

A relação entre alfabetização e cidadania tem sobrevivido, e com bastante fôlego, como a mais importante fórmula pensada para resolver a inclusão do conjunto da população na ordem política, social e econômica nestes quase três séculos de hegemonia do modelo civilizatório burguês.

Movidos, historicamente, pelos modelos político, social e econômico liberal, os defensores desses modelos vêm se servindo, abundantemente, do suporte ideológico tensionado nesta relação, cujo objetivo parece ser o de dar substância e materialidade ao sentido da cidadania como produto acabado das políticas de alfabetização.

Ao reler o mapeamento das principais campanhas de alfabetização - no século passado - iniciadas com maior vigor nos anos 20, nas chamadas Ligas contra o Analfabetismo; a Campanha de Educação de Adolescentes e Adultos, nos anos 40; a Cruzada ABC em meados dos anos 60; o Movimento Brasileiro de Alfabetização (MOBRAL), nos anos 70 e o PAS, no final dos anos 90, identifiquei terem estes programas, em comum, a produção ideológica da alfabetização como o principal dispositivo capaz de ativar a cidadania.

A participação deste pressuposto me levou a formular a seguinte questão: seria possível falar de uma ação pedagógica ${ }^{6}$ nas políticas governamentais de alfabetização de 
jovens e adultos que negue a cidadania de quem delas participa ? Ou seja, uma cidadania às avessas caracterizada pela ausência, pela falta da leitura e da escrita?

Sem tocar no modelo de Estado que a sedimentou, a ação pedagógica de negação da cidadania será, já na sociedade moderna e industrial, justificada ora se ancorando na crença de que a alfabetização irá contribuir para a propagação dos ideais liberais democráticos, ora, e combinada à primeira crença, como apelo para se alcançar o desenvolvimento econômico, conduzindo o país a lograr êxitos econômicos e, assim, atingir a (pós)modernidade.

A minuciosa pesquisa de Paiva (1973) nos fornece valoroso material sobre os sentidos oficiais que caracterizaram as representações sobre o analfabetismo e o analfabeto, especialmente a partir da década de 1940 até o início da década de 1970, e que nos ajuda a identificar a tese da menoridade do analfabeto presente nas políticas de alfabetização.

Assim, veremos que na primeira campanha de alfabetização de jovens e adultos, instituída no Brasil, a CEAA (Campanha de Educação de Adolescente e Adultos - 19471963), Lourenço Filho, seu presidente e organizador, compara o analfabetismo ao marginalismo social, econômico e cultural e, ao afirmar que o adulto analfabeto é um ser marginal, sentencia-o anunciando que este "não pode estar ao corrente da vida nacional".

Para os liberais brasileiros, o analfabeto padeceria da menoridade econômica, política e jurídica, pois

(...) produz pouco e mal e é freqüentemente explorado em seu trabalho; não pode votar e nem ser votado; não pode praticar atos de direito. $\mathrm{O}$ analfabeto não possui, enfim, sequer os elementos rudimentares da cultura de nosso tempo (PAIVA, idem, p.184 ).

Estes sentidos estarão uma vez mais sendo reafirmados nas campanhas que viriam a ser posteriormente deflagradas, resguardadas as devidas considerações que os seus respectivos contextos históricos delimitam, tais como a Cruzada ABC (1966-1970) e o MOBRAL (1970-1985).

Essas duas campanhas, criadas pelo autoritarismo obscurantista do regime militar, substituíram os movimentos de educação e cultura popular que emergiram no período entre 1959 e 1964. Movimentos estes que foram embalados pelo clima existente no país de reivindicação das reformas de base e pelas liberdades democráticas vivido no contexto dos governos anteriores ao golpe político-militar de $64^{7}$.

Sustentada financeiramente pela Agência dos Estados Unidos da América para Desenvolvimento Internacional (USAID), pelos generosos recursos do governo federal, pela colaboração das administrações estaduais e de algumas instituições internacionais, a Cruzada $\mathrm{ABC}$ seria entregue, política e pedagogicamente, à orientação norte-americana (NUNES, 1993).

Sua projeção ficará registrada, na história das políticas governamentais de alfabetização de jovens e adultos, como uma das iniciativas de maior expressão promovidas pelo MEC à época, cuja tarefa, alimentada pela motivação política dos setores sociais que apoiaram o movimento golpista de 64, tentará neutralizar as idéias difundidas pelas campanhas anteriores, principalmente em relação àquelas inspiradas nas orientações do pensamento marxista.

Tal motivação política criará novas condições para a retomada da tese da inferioridade e incapacidade do analfabeto. Assim, as concepções produzidas sob o império dessa tese irão ser realimentadas por diversas medidas que, ao lado da Cruzada ABC, compunham o "esforço" governamental na erradicação do analfabetismo. 
Em relação a esses esquemas teóricos um recorte feito sobre trabalho de Paiva (1973, p. 266-267), a propósito dos discursos dominantes do período confirma a negação da cidadania, os direitos sociais e políticos do analfabeto ${ }^{8}$ :

(...) os marginalizados (analfabetos) mal produzem e consomem abaixo do mínimo. Não imaginam, não se dedicam, não estimulam, não competem, não se aperfeiçoam. Constituem, sob todos os aspectos, a mais perigosa parcela contra o desenvolvimento. 9

Sobre o sentido deste enuncido, percebe-se o fortalecimento da ideologia do modelo econômico desenvolvimentista adotado pelo Estado brasileiro e pela burguesia industrial que exigia, naquele estágio de desenvolvimento em que se encontrava o país, um maior número de brasileiros com capacidade de expressão e raciocínio integrados no meio físico e social (p. 264) ${ }^{10}$.

Tal como as iniciativas anteriores, engendradas pelo regime militar, o MOBRAL (1970-1985) irá fortalecer a ideia do analfabetismo como responsabilidade do indivíduo, como um problema de causa isolada e individual, sem relacioná-lo, por isso mesmo, às questões sociais, políticas e econômicas responsáveis pela sua produção. Ao mesmo tempo, irá enfatizar a alfabetização como condição essencial para o desenvolvimento econômico do país.

A idéia da menoridade do sujeito analfabeto se explicita, não apenas, nos discursos oficiais dos programas de alfabetização anteriormente desenvolvido. A sua legitimação, pelo silenciamento de sentidos, estará presente nas vozes dos alfabetizandos de Jaramataia participantes do Programa Alfabetização Solidária:

- Eu acho que eu não aprendo, porque eu não tenho cabeça. Eu sou uma pessoa muito analfabeta. Daí, não saber dizer as coisas que é preciso (Rivaldina, trabalhadora rural de aluguel, 27 anos).

A concepção do analfabetismo como menoridade representa uma das formas de silenciamento das classes populares e permite sustentar a inter-relação entre alfabetização e cidadania.

A "ideologia do analfabetismo", expressão elaborada por Ana Maria Freire (1994), nos ajuda a pensar sobre esta forma de silenciamento. A autora confirma que a relação entre alfabetização e cidadania está sedimentada como uma das expressões que irá justificar a interdição e a exclusão das classes trabalhadoras do poder e da participação política.

Sob a ideologia do analfabetismo, as elites dominantes vêm justificando e naturalizando a idéia de que a cidadania, a participação nos assuntos importantes de um país, é consequiência da alfabetização. Assim, se nem todos são cidadãos ou têm direitos de cidadania, é porque lhes falta o domínio do código escrito para conferir-lhe o passaporte à cidadania.

O projeto social, derivado deste pensamento, irá gravar a educação como passagem natural para a transformação dos antigos servos em cidadãos ocultando, desse modo, as condições econômico-sociais profundamente excludentes.

Mantida através desta ordem, a relação entre alfabetização e cidadania, cuja ideologia dá sustentação ao processo de ocultamento de tais contradições, atribui ao indivíduo aquilo que lhe falta para ser cidadão.

Nesse sentido, é importante revisitar os processos pelos quais surgiu a concepção da cidadania moderna e lembrar que, após o triunfo das revoluções liberais-burguesas no 
final do século XVIII, um dos debates mais fecundos girava em torno da discussão sobre os critérios que deveriam diferenciar os cidadãos ativos dos cidadãos passivos em face dos direitos de cidadania pactuados pela "Declaração dos Direitos do Homem e do Cidadão".

A ideia concreta da soberania do povo ou a sua participação direta acabou sendo derrotada, predominando uma concepção de democracia estritamente ligada à representação da nação, "encarnada pela Assembléia" dos cidadãos ativos, ou seja, aqueles que usufruíam da condição de proprietários e de cidadãos (BENEVIDES, 1994).

Como o critério para ser considerado cidadão era ser proprietário, só os proprietários é que poderiam ter direito a participar da vida do Estado, usufruindo dos seus benefícios. Esse critério, no entanto, foi refinadamente elaborado pelo movimento liberalburguês que encontrará no pensamento de Imanuel Kant uma poderosa e quase invencível tese que viria afirmar a perspectiva da nova classe dominante sobre os direitos de cidadania.

Em seu texto "O que são as luzes", este filósofo alemão irá defender que, para ser cidadão, era preciso participar na vida pública do Estado, possibilidade esta somente garantida pelo que ele veio a chamar de direito público das Luzes, ou seja, da razão.

A respeito da análise das "luzes", a tônica kantiana (apud SOROMENHOMARQUES, 1996, p.56) será dirigida para a responsabilidade individual e a necessidade de as "luzes" só poderem ser compreendidas e assumidas plenamente no interior do processo de criação, no seio da sociedade de um espaço público:

As Luzes são a saída do homem do estado de menoridade, de que ele próprio é culpado. Menoridade é a incapacidade de se servir do seu próprio entendimento, sem a direção de um outro.

Kant não hesitará em considerar as Luzes como sendo o mais importante estado para se alcançar a maioridade racional. O princípio das Luzes será decisivo quando colocado diretamente no terreno aberto, pós-revoluções, sobre que qualidades deveriam ter os homens aos quais caberia decidir sobre os assuntos que diziam respeito aos interesses comuns da sociedade.

Sem maioridade, os indivíduos não têm direito ao uso público da razão, são menos voluntários, não têm "coragem" de se servir do exercício crítico da razão, não conseguem acumular riqueza e propriedades. A estes, então, devem ser vetados os direitos civis e os direitos políticos.

Mas quem seriam os "menores" da razão?

Os "menores" no uso da razão seriam todos aqueles e aquelas que se mantivessem sob a dependência de um outro para poder sobreviver: os trabalhadores não-proprietários, as mulheres, as crianças. Enfim, seriam todos aqueles não-proprietários, como identificou Benjamin Constant (apud CHAUÍ,1989, p. 41-42):

(...) aqueles que a pobreza retém numa eterna dependência e que condena a trabalhos cotidianos não são pessoas esclarecidas (...). Não sabem pensar.

(....) Assim a condição para ser um cidadão politicamente reconhecido é o lazer, indispensável para a aquisição das Letras e a retidão do julgamento. Somente a propriedade torna os homens capazes de direitos políticos. 
Segundo o ideário liberal-burguês, todos os homens são iguais, tendo direito à liberdade, à proteção de sua pessoa e de sua crença porque estas são bens naturais, são suas "propriedades" e, por isso, devem ser protegidas.

Como o projeto liberal-burguês não foi capaz de superar o seu caráter meramente abstrato, ou seja, de que todos os homens são iguais e livres perante o escopo jurídico, a declaração de emancipação política e da igualdade passa a ser limitada ao discurso formal, mas não a uma prática e condições concretas de realizá-las.

Marx (2000) é quem primeiro irá explicitar este conflito e contradição do liberalismo presentes na base da concepção da igualdade. A concepção da igualdade, enquanto idéia-força da burguesia, irá nutrir, abstratamente, as relações sociais e econômicas do projeto liberal.

A crítica feita por Marx, em relação à perspectiva liberal de cidadania, denuncia a incompatibilidade entre emancipação política e humana sob as bases da produção capitalista, a idéia da igualdade era contraditória em relação às leis que regiam a produção econômica capitalista.

Por isso mesmo, parece ser decorrente desta idéia o fato de a cidadania política ser a justificativa encontrada pelos liberais para celebrar a igualdade. Buffa (1987) nos lembra que o que estava contido na defesa desta idéia abstrata da cidadania não era a formação de um novo homem para uma nova sociedade, via educação, mas a separação entre proprietários e não-proprietários, cuja gênese se fundamentava na propriedade dos meios de produção econômica.

Desse modo, confirma-se a tese marxiana sobre o sentido abstrato do direito de igualdade, pois a concepção liberal de cidadania concentrava-se na idéia de que só a propriedade era a garantia contra a arbitrariedade do Estado sobre os cidadãosproprietários, únicos capazes de usufruírem dos direitos políticos.

$\mathrm{Na}$ ascensão do liberalismo, a conveniência de se educar os não-cidadãos será efetivada pelos aspectos mais essenciais do ensino da leitura, da escrita e dos rudimentos elementares do cálculo. Tratava-se de uma educação nivelada, porque o trabalho na manufatura fora nivelado. Dentro desta nova ordem econômica da manufatura não se exigia o trabalhador qualificado, mas, sim, o trabalhador disciplinado.

A institucionalização da educação, em seu processo organizativo, estruturado pela via da escolarização, irá assumir importância vital para a afirmação do novo modo de produção material e econômica da sociedade capitalista e, neste sentido, estará associada à idéia de preparação da mão-de-obra de trabalhadores não qualificados, instrumentalizandoos com as habilidades econômico-produtivas necessárias para o desempenho das novas funções que passaram a ser exigidas por esta sociedade.

Educação e alfabetização ganhavam, deste modo, um sentido ideológico importante para as classes dominantes que, assim, ocultavam as reais intenções de consolidação do seu projeto social e o seu modelo de acumulação de riqueza.

Ao mesmo tempo, alfabetização e cidadania eram "traduzidas", ideologicamente, para as classes subordinadas como únicas possibilidades de acesso e conversão à cidadania, ou seja, o sentido desta conversão era estimulada mais pelo seu conteúdo político, abstrato, do que pelo seu conteúdo econômico-social.

O novo Estado liberal-burguês reinventará a idéia que irá consagrar o direito de todos à participação ativa na sociedade. Para isso era preciso que todos ingressassem na cultura letrada, sem a qual não chegariam a ser sujeitos de direitos, ou seja, não gozariam da cidadania política como base da igualdade entre os indivíduos.

No Brasil, as exposições de motivos das campanhas ou programas oficiais de alfabetização de jovens e adultos, com características de maior ou menor duração, parecem 
legitimar o sentido oficial do analfabeto como um "menor da razão". O analfabeto é representado como "cego", "economicamente improdutivo", "excluído" ou "órfão" dos bens e serviços oferecidos pela sociedade moderna e seu fabuloso mercado.

Assim, enquanto não são alfabetizados, é justificada a idéia de não serem cidadãos, de não contribuírem e de não participarem da dinâmica das relações sociais de produção.

A sua origem encontra-se vinculada ao minucioso trabalho dos jesuítas que, ao tentarem instalar uma poderosa pedagogia da negação das práticas culturais indígenas, irão desenvolver ações pedagógicas cingidas pelo medo, pelo apagamento dos costumes e a substituição de uma visão de mundo em nome de uma outra considerada superior.

"Tudo é papel em branco" 11 se constituirá na primeira metáfora ideológica e explicativa da ação pedagógica de negação da cidadania dos dominantes para representar os dominados, nomeando-os e determinando a sua posição de inferioridade em relação à ordem econômico-social implantada pelo poder da sociedade colonial e escravocrata.

Pode ser constatado que as políticas governamentais de alfabetização de jovens e adultos no Brasil tem sido presididas por sistemas de representações que integram mecanismos de produção, interpretação e visão de mundo das classes dominantes.

Para essas classes, existe uma incapacidade quase natural dos analfabetos para decidir, pensar a sua realidade e produzir cultura. Por isso mesmo dependem das idéias, dos valores culturais, da linguagem das elites que devem ser tomados como faróis a iluminar o povo inferior, incapaz e desprotegido.

$\mathrm{O}$ funcionamento destes mecanismos tem associado pares contrastantes na orientação e justificação das políticas governamentais de alfabetização, tais como cegueira $\mathrm{x}$ iluminação; incapacidade $\mathrm{x}$ capacidade; improdutividade $\mathrm{x}$ produtividade $\mathrm{e}$, ao atribuírem uma natureza redentora às políticas de alfabetização, disseminam a crença de que o povo, sem a alfabetização, não possui capacidade para ser protagonista da história, de construir o movimento dialético de fazê-la e transformá-la.

À luz dessa concepção redentora e salvacionista, as políticas de alfabetização tem se servido desses pares contrastantes para consolidar os projetos e objetivos políticos definidos. Assim, ao rastrear as principais campanhas de alfabetização de jovens e adultos no Brasil podem ser postos, em relevo, alguns sentidos produzidos sobre o analfabetismo e o analfabeto, identificando neles os modelos de cidadania ou seu oposto, a não-cidadania.

A partir dos encaminhamentos teóricos com os quais busquei fundamentar a pesquisa, percebi que a renovação do repertório interpretativo pelas classes dominantes nos oferece a possibilidade de construir uma argumentação que explicite a alfabetização, tomada como fronteira que separaria o cidadão do não-cidadão, como um dos instrumentos de discriminação e desigualdade veiculadas pela ideologia dominante.

A evocação das metáforas "cegueira" e "orfandade" sintetiza a forma predominante, não só para se descrever o sujeito não alfabetizado e o analfabetismo estimulando a participação deste em campanhas, além de mobilizar a sociedade através da indução à comoção da caridade -, mas, principalmente para se engendrar a intimidação social (CHAUÍ, 1989, p. 35).

A intimidação social trabalha para tentar produzir nos sujeitos não alfabetizados ou pouco escolarizados um juízo de valor, segundo o qual, por não serem portadores de um saber socialmente reconhecido - a leitura e a escrita -, estes se sentiriam, não somente destituídos deste saber, mas "despojados de uma humanidade válida", impedindo as classes populares de dizerem a sua própria palavra.

Ao nosso ver, estas metáforas reatualizam o sentido da alienação, ou seja, ocultam a divisão social, o desaparecimento das contradições que está na base da produção social do trabalho e das desigualdades sociais. 
Acontece que nem sempre a lógica que imprime estas representações exibe evidências fáceis de serem percebidas por toda a comunidade humana. De maneira que a sua não explicitação, nas políticas de alfabetização, tentará gerar uma astuta forma de negação da cidadania, pois cria uma aura de legitimidade para as intencionalidades do capital, seja ele produtivo ou financeiro, fixando o sujeito em um determinado lugar na produção social do trabalho.

Se desconsiderarmos o próprio objeto da alfabetização, ou seja, a escrita enquanto produção histórica, social e cultural, estaremos abdicando de compreender as formas de negação da cidadania. Historicamente, a palavra escrita está associada, desde as suas origens, na composição dialética dominação/subordinação; participação/exclusão, dentro de um complexo movimento histórico e de construção da hegemonia de uma determinada classe.

Em pesquisa realizada para o processo de doutoramento concluído na UFRJ, em 2003, no município Jaramataia incrustado no sertão do Estado de Alagoas, durante as entrevistas feitas com os alfabetizandos (no período de 1999 a 2002) era bastante comum ouvir em suas vozes o sentido de que a pessoa que não sabe ler nem escrever é como um "cego":

- Mas, você não "enxerga"?

- Enxergar, eu enxergo, mas é o caso de querer ir pra algum lugar, sem precisar ficar dependendo dos outro pra tomar ônibus (...), ir no mercado, vê um produto.

- Então, é uma "cegueira" diferente...

- É quase igual, ver sem ler, não tem muita valia...(Ivaneide, tecelã de rede de pesca, 22 anos).

Por entre as vozes dos autores que participam deste diálogo vimos tentando compreender qual a lógica ou quais lógicas estariam presentes na metáfora da cegueira, isto é, como ela foi, historicamente, construída. Entretanto, uma outra pergunta emendei à minha indagação: como, principalmente ela é refletida e refratada nos enunciados dos alfabetizandos?

Nesses diálogos, pareceu-me que, ser "cego" - porque analfabeto -, pode ser compreendido pela disseminação ideológica que se tornou dominante graças à artesania ideológica da racionalidade liberal. Para esta concepção, quem não lê nem escreve, não possui capacidade para compreender e, portanto, não vê.

Por esta perspectiva, aos sujeitos não alfabetizados é-lhes imputado o silenciamento, pois estes devem reproduzir o sentido dominante que precisa ser repetido para ser "ouvido" e ressonado através dos tempos nas longas temporalidades dialógicas, como nos diz Bakhtin (2000).

Numa sociedade como a nossa, fundada em relações sociais, políticas e econômicas desiguais e excludentes, condicionar ao ordenamento da escrita o movimento de compreensão que homens e mulheres devem fazer sobre a realidade,significa querer subordinar este movimento à visão de mundo e à ética das classes dominantes, já que estas tentam tornar invisíveis e inaudíveis, portanto, incompreensíveis as contradições produzidas pelo modelo de sociedade que defendem e tentam perpetuar.

Este sentido reforça a idéia que foi transformada em senso comum pela ideologia dominante que determina o que deve e precisa ser dito, construindo, dessa forma, a hegemonia de sentido pela via do silenciamento, determinando a alfabetização como única resposta possível:

- Eu mesmo me considerava um cego. Por isso eu queria aprender a ler.(...)

Pra ter qualidade (Cléber, trabalhador rural e pescador, 21 anos); 
Como se pode reparar, esses enunciados refletem a concepção da ideologia dominante e uma síntese irretocável do poder por ela operado ao atribuir à alfabetização a fórmula eficiente para tornar o sujeito não alfabetizado em cidadão.

De uma certa maneira, tem-se constatado facilmente que as políticas governamentais de alfabetização de jovens e adultos, exceto em alguns períodos de tensão político-ideológicos, têm sido subordinadas à lógica e à necessidade do capital.

\section{CONSIDERAÇÕES FINAIS}

Nas discussões feitas anteriormente, pude afirmar que a tradição prático-teórica do liberalismo, ao reduzir a relação entre alfabetização e cidadania a uma relação de causa e efeito, parece adaptar-se aos diferentes contextos históricos onde emergem as políticas de alfabetização de jovens e adultos; em particular àqueles contextos que marcam a passagem da economia brasileira de uma sociedade agrário-exportadora para uma sociedade de economia capitalista industrial e dependente, na periferia da globalização.

Nesse sentido, é relevante lembrar que, ao menos no Brasil, as políticas de alfabetização têm sido orientadas pelos organismo internacionais, em especial a Unesco (Organização das Nações Unidas para a Educação, a Ciência e a Cultura), com mais ênfase nas décadas de 60 e 70 e o Banco Mundial na década de 90.

Especialmente, a partir dos anos 60, estas campanhas de alfabetização passaram a ser impulsionadas pelo modelo desenvolvimentista, tendo como inspiração a teoria do capital humano, que passa a ser prescrita como solução para o enfrentamento da pobreza e a exclusão social entre países em desenvolvimento e subdesenvolvidos, bem como entre os próprios indivíduos, como alternativa para a diminuição das desigualdades sócioeconômicas.

A crença na alfabetização como fator de desenvolvimento e do progresso econômico tem impulsionado o Programa Alfabetização Solidária ao privilegiá-la como principal instrumento contra a exclusão social e, conseqüentemente para a aquisição de direitos.

A análise crítica desenvolvida por este autor permite compreender que, mesmo nos anos 90, a passagem da ideologia do desenvolvimento à ideologia da globalização deu novas vestes à teoria do capital humano.

Pareceu-me claro também, o caráter ou a concepção de alfabetização funcional adotada pelo PAS e que muito interessa às demandas da economia capitalista. Esta perspectiva tem sido confirmada por Giroux (apud MACEDO, 2000, P.88), ao acentuar que as políticas de alfabetização têm sido informadas por ideologias que imputam à alfabetização um valor definido e medido pela exigência daquelas habilidades de ler e escrever necessárias para a expansão do processo de trabalho envolvido na produção em massa de informação, comunicação e finanças.

Abrigada na concepção funcionalista, a ideologia do analfabetismo e da menoridade do sujeito não alfabetizado são fortalecidas como mecanismo que embaça a concepção da alfabetização enquanto práxis social e criativa de homens e mulheres ao mesmo tempo que ofusca o sentido da cidadania enquanto constelação de direitos sociais, culturais, econômicos e políticos.

A análise, até aqui feita sobre as políticas de alfabetização de jovens e adultos, permite inferir que, apesar da aparência monolítica, as ideologias dominantes trazem, desde as suas origens, brechas que denunciam a sua articulação com o poder e a dominação, dando visibilidade às suas inerentes contradições. Ao dizer assim, pretendo 
afirmar que a alfabetização, tomada como processo de apoderamento da palavra escrita, pode reinventar a própria cidadania dos que dela e em seu nome foram silenciados e excluídos. Em face do seu caráter contraditório, Freire (1989, p. 15) nos ensina que a alfabetização, como veículo de uma ideologia dominante,

(...) não tem força necessária para concretizar pelo menos algumas ilusões que veicula (...) cedo ou tarde termina por funcionar contra os objetivos amaciadores do próprio sistema cuja ideologia ela reproduz.

Compartilho com ele a concepção crítica de que a subalternidade do sujeito analfabeto, não é originária de uma natureza intrínseca, ou seja, não se trata de uma falta ou uma "enfermidade" como a "cegueira", mas de uma condição concreta, imposta pela realidade social injusta e historicamente produzida.

Esta concepção crítica nos leva a defender radicalmente a idéia de que as políticas governamentais de alfabetização, oferecidas aos jovens e adultos não podem ser instituídas por ações pedagógicas de negação da cidadania que consagram o acesso à leitura e à escrita como prática de alforria e de redenção, da benesse e da caridade pela ideologia da classe que a promove.

\section{REFERÊNCIAS BIBLIOGRÁFICAS}

ADIGA, A. O Tigre Branco. Rio de Janeiro: Nova Fronteira, 2008.

ALVARENGA, M. S. A inter-relação entre educação popular e organização comunitária como um fator de contribuição à construção da cidadania. Dissertação de mestrado. UFRJ, 1991.

BAKHTIN, M. Estética da criação verbal. São Paulo: Martins Fontes, 2000.

BENEVIDES, M.V. Cidadania e democracia. São Paulo: Lua Nova, CEDEC, n.33, 1994.

BETTO, Frei. A avareza. In. SADER, E. (org.). 7 Pecados do Capital. 3. ed. Rio de Janeiro: Record, 2000.

BUFFA, E. Educação e cidadania burguesas. In Buffa, Arroyo e Nosella (orgs.). Educação e Cidadania: quem educa o cidadão. São Paulo: Cortez, 1987.

CARVALHO, J. M. Desenvolvimiento de la ciudadania en Brasil. México: Fondo de Cultura, 1995.

CHAUÍ, M. Conformismo e resistência. São Paulo: Brasiliense, 1989.

FAORO, R. Os donos do poder. São Paulo: Ed. Globo, 1995.

FREIRE, P. A importância do ato de ler: em três artigos que se completam. São Paulo: Cortez, 1989.

MACEDO, D. Alfabetização, linguagem e ideologia. In. Revista Educação \& Sociedade. São Paulo, nº 73/2000, p. 84-99.

MARTINS, J. S. O Poder do Atraso. São Paulo: Hucitec, 1993.

MARSHALL, T. H. Cidadania, classe social e status. Rio de Janeiro: Zahar, 1967.

MARX, K. A questão judaica. São Paulo: Moraes, 2000.

NUNES, C. Uma visão histórica da educação de adultos no Brasil, Niterói, UFF, Cadernos ESSE, nº $1,1993$.

PAIVA, V. Educação Popular e Educação de Adultos, São Paulo: Loyola, 1973. 
PROGRAMA ALFABETIZAÇÃO SOLIDÁRIA. Mil dias reescrevendo o Brasil: relatório de três anos de atividade. Brasília, Conselho Consultivo da Coordenação das Universidades do Programa Alfabetização Solidária, 2000.

RODRIGUES, J. H. Conciliação e Reforma no Brasil. Um desafio histórico-político. Rio de janeiro: Civilização Brasileira, 1981.

SANTOS, M. Por uma outra globalização. Rio de Janeiro: Civilização Brasileira, 2000. . O espaço do cidadão. São Paulo: Nobel, 1996.

SANTOS, W. G. Cidadania e Justiça: a política social na ordem brasileira. Rio de Janeiro: Campus, 1987.

SILVA, M. História do Analfabetismo no Brasil. Campinas. Unicamp, Tese de Doutorado, 1998.

SOROMENHO-MARQUES, V. A era da cidadania - De Maquiavel a Jefferson. Portugal: Publicações Europa - América Ltda, 1996.

\footnotetext{
${ }^{1}$ Doutora em Educação pela Universidade Federal do Rio de Janeiro (2003). Professora da Graduação e do Programa de Pós-Graduação Mestrado em Educação Processos Formativos e Desigualdades Sociais da Faculdade de Formação de Professores da UERJ (FFP/UERJ). Pesquisadora do CNPq (2008-2010). Membro do GT Educação de Pessoas Jovens e Adultas da ANPED e membro do Grupo de pesquisa "Vozes da Educação: História e Memória das Escolas de São Gonçalo" com atuação na linha de pesquisa Políticas Públicas, direitos e desigualdades. E-mail msalvarenga@uol.com.br

${ }^{2}$ Carvalho (1995, p. 48) descreve que essa prática não era privativa das elites, pois quase toda a sociedade aceitava os valores da escravidão. Inclusive, não era raro ver escravos libertos como proprietários de escravos.

${ }^{3}$ Pronunciamento do liberal Antonio Felício dos Santos (apud, RODRIGUES, 1981).

${ }^{4}$ Para Frei Betto (2000, p.14), a avareza é a alma do sistema capitalista, "a paixão pelo dinheiro". Para este sistema não é importante saber sobre os caminhos éticos adotados para acumular tanta fortuna. Os avarentos são os vencedores. Estes valem, não pela pessoa que são, mas pela riqueza que ostentam.

${ }^{5}$ Em entrevista ao Jornal do Brasil, em 26/12/1998, por ocasião do título recebido naquele ano de "Homem de Idéias".

${ }^{6}$ Achei conveniente tomar de empréstimo esta expressão construída por Martins (1993, p. 16) ao designar a forma pela qual a sociedade brasileira foi submetida a um processo cotidiano de tentativa de transformação dos seus valores culturais em "valores negativos da sociabilidade do novo mundo", inaugurado pela política social e econômica no período colonial.

${ }^{7}$ Na dissertação de mestrado (ALVARENGA, 1991), analiso, no capítulo "Democracia, Movimentos Sociais e Educação Popular", a contribuição dos movimentos de educação e cultura popular como instrumentos de luta e práxis da cidadania.

${ }^{8}$ É necessário lembrar que o direito do analfabeto ao voto só foi conquistado em 1988, quando aprovada e proclamada a Constituição Federal, após duas décadas de ditadura militar.

${ }_{9}^{9}$ Celso Kelly, substituto de Edson Franco na direção do Departamento Nacional de Educação, 1966, (citado em PAIVA, 1973)

${ }^{10}$ Clóvis Salgado, presidente da Câmara de Planejamento do Conselho Federal de Educação, 1966 (citado em PAIVA, 1973).

${ }^{11}$ Expressão usada pelo padre Manoel da Nóbrega em carta destinada à metrópole para descrever o índio brasileiro como desprovido de humanidade e qualquer vestígio de civilização. Ver a íntegra desta carta em Silva (1998), em sua tese de doutoramento pela Unicamp.
}

Artigo recebido em: 18/08/09

Aprovado para publicação em: 02/02/10 